Article

\title{
Chemical Composition and Bioactivities of the Essential Oil from Etlingera yunnanensis against Two Stored Product Insects
}

\author{
Shan-Shan Guo ${ }^{1}$, Chun-Xue You ${ }^{1}$, Jun-Yu Liang ${ }^{1}$, Wen-Juan Zhang ${ }^{1}$, Zhu-Feng Geng ${ }^{1,2}$, \\ Cheng-Fang Wang ${ }^{1}$, Shu-Shan Du ${ }^{1, *}$ and Ning Lei ${ }^{3, *}$
}

1 Beijing Key Laboratory of Traditional Chinese Medicine Protection and Utilization, Beijing Normal University, No.19 Xinjiekouwai Street, Beijing 100875, China;

E-Mails: guoshanshan@mail.bnu.edu.cn (S.-S.G.); youchunxue@mail.bnu.edu.cn (C.-X.Y.); liangjunyu@nwnu.edu.cn (J.-Y.L.); zwj0729@mail.bnu.edu.cn (W.-J.Z.); gengzhufeng@bnu.edu.cn (Z.-F.G.); wangchengfang@mail.bnu.edu.cn (C.-F.W.)

2 Analytical and Testing Center, Beijing Normal University, Beijing 100875, China

3 Department of Pharmacy General Hospital of Second Artillery, PLA, Haidian District, Beijing 100088, China

* Authors to whom correspondence should be addressed; E-Mails: dushushan@bnu.edu.cn (S.-S.D.); lilyzebra@163.com (N.L.); Tel./Fax: +86-10-6220-8022 (S.-S.D.);

Tel.: +86-10-6334-3252 (ext. 8002) (N.L.); Fax: +86-10-6207-6963 (N.L.).

Academic Editor: Derek J. McPhee

Received: 14 July 2015 / Accepted: 21 August 2015 / Published: 28 August 2015

\begin{abstract}
The chemical composition of the essential oil of Etlingera yunnanensis rhizomes and its contact and repellent activities against Tribolium castaneum (Herbst) and Liposcelis bostrychophila (Badonnel) were investigated. The essential oil obtained from E. yunnanensis rhizomes with hydrodistillation was performed by gas chromatography-flame ionization detection and gas chromatography-mass spectrometry. The main components of the essential oil were identified to be estragole $(65.2 \%), \beta$-caryophyllene $(6.4 \%), 1,8$-cineole $(6.4 \%)$, limonene (5.2\%), and $\alpha$-pinene (2.4\%). It was found that the essential oil of E. yunnanensis rhizomes possessed contact toxicity against $T$. castaneum and L. bostrychophila $\left(\mathrm{LD}_{50}=\right.$ $23.33 \mu \mathrm{g} /$ adult and $\mathrm{LD}_{50}=47.38 \mu \mathrm{g} / \mathrm{cm}^{2}$, respectively). Estragole, 1,8-cineole, and limonene exhibited stronger contact toxicity ( $\mathrm{LD}_{50}$ values of 20.41, 18.86, and $13.40 \mu \mathrm{g} / \mathrm{adult}$, respectively) than $\beta$-caryophyllene $\left(\mathrm{LD}_{50}=41.72 \mu \mathrm{g} / \mathrm{adult}\right.$ ) against $T$. castaneum adults. Estragole possessed stronger contact toxicity $\left(\mathrm{LD}_{50}=30.22 \mu \mathrm{g} / \mathrm{cm}^{2}\right)$ than $\beta$-caryophyllene, 1,8-cineole, and limonene (LD50 values of 74.11, 321.20, and $239.62 \mu \mathrm{g} /$ adult, respectively)
\end{abstract}


against $L$. bostrychophila adults. Repellency of the crude oil was also evaluated. The essential oil and constituents possessed strong repellent activity against $T$. castaneum adults. The four individual constituents showed weaker repellent activity than the essential oil against L. bostrychophila adults. The results indicated that the essential oil of E. yunnanensis rhizomes and the individual constituents had the potential to be developed as a natural insecticide and repellent for the control of T. castaneum and L. bostrychophila.

Keywords: Etlingera yunnanensis; contact activity; repellency; composition; stored product insects

\section{Introduction}

The widespread extensive use of synthetic insecticides has triggered many negative consequences (i.e., insecticide resistance, toxicity to mammals and other non-target animals, residue problems, environmental pollution) [1,2]. Risks associated with the use of synthetic insecticides have led to the growth of an environmental movement seeking sustainable alternatives in pest control [3]. Therefore, increasing attention is being given to natural products. Plants can provide potential alternatives to the currently used insecticides that seem to cause insecticide resistance and environmental and human health concerns because they constitute a rich source of bioactive chemicals, such as terpenoids, alkaloids, and avonoids, against insects, and they have evolved strategies to interact with other organisms for self-defense [4]. Many essential oils and their constituent compounds from plants have been evaluated for repellency and insecticidal activity against stored product insects and some of them are quite promising in the development of natural repellents or insecticides [5-9].

In ancient China, extracts of many medicinal herbs and spices were used to control grain storage insects and pests [10]. Moreover, a traditional Chinese medicinal material conservation method called antagonistic storage has also been used for medicinal materials that have special volatile odors to prevent the insects in other medicinal materials [11]. However, the gap between unsubstantiated traditional use and experimentally substantiated potential should be bridged. Thus, based on the experimental evidence, this traditional method should be developed and inherited.

In order to develop this traditional method of prevention and control of storage pests, we have established a screening program and focus on the volatile substances due to their major role in the antagonistic storage process. During this screening process, the essential oil of Etlingera yunnanensis (T.L. Wu and S.J. Chen) R.M. Smith [12] was found to possess insecticidal activity against the red flour beetle, Tribolium castaneum Herbst, and the booklouse, Liposcelis bostrychophila Badonnel. The red flour beetle is one of the most widespread and destructive insect pests of stored cereals, and can be found where grains or other dried foods are stored [13]. Infestations not only cause significant losses due to the consumption of grains but also result in elevated temperature and moisture conditions, which lead to accelerated growth of molds, including toxigenic species [14]. Booklice have a worldwide distribution infesting domestic premises, raw material stores, manufacturing factories, and historical documents in museums. Additionally, new evidence indicates that psocids are perhaps the most important emerging pests in stored grains and related commodities due to their small size, and resistance to chemicals [15]. 
Etlingera, a genus in Zingiberaceae, has only two species, Etlingera littoralis and Etlingera yunnanensis, distributed in China [16]. E. yunnanensis is a perennial herb, and it has an attractive inflorescence-like chrysanthemum. When it is frayed, it releases an anis-like odor [12]. It is commonly used in Dai medicine and is called "Maniangbu" in a different clinical usage, i.e., for diarrhea and sunstroke [17]. A literature survey has shown that there is neither a report on the chemical composition of E. yunnanensis rhizomes essential oil nor a report on its insecticidal and repellent activity. Therefore, we decided to evaluate the contact and repellent activity of the essential oil of E. yunnanensis rhizomes and its main compounds against two stored product insects.

\section{Results and Discussion}

\subsection{Chemical Composition of the Essential Oil}

The yield of yellow essential oil from E. yunnanensis rhizomes was $0.14 \%(\mathrm{v} / w)$ and the density of the essential oil was determined to be $0.97 \mathrm{~g} / \mathrm{mL}$. The chemical composition of the essential oil was summarized in Table 1. A total of 12 compositions of the essential oil were identified. The principal components of the essential oil were estragole (65.2\%), $\beta$-caryophyllene (6.4\%), 1,8-cineole (6.4\%), and limonene (5.2\%) (Figure 1).

Table 1. Chemical composition of Etlingera yunnanensis essential oil.

\begin{tabular}{|c|c|c|c|}
\hline Peak No. & Compound & RI * & Area \% \\
\hline 1 & $\alpha$-Pinene & 932 & 2.4 \\
\hline 2 & Camphene & 943 & 0.1 \\
\hline 3 & Limonene & 1029 & 5.2 \\
\hline 4 & 1,8-Cineole & 1032 & 6.4 \\
\hline 5 & Camphor & 1120 & 1.0 \\
\hline 6 & $\alpha$-Terpineol & 1189 & 0.6 \\
\hline 7 & Estragole & 1197 & 65.2 \\
\hline 8 & Dodecane & 1203 & 0.1 \\
\hline 9 & Isobornyl acetate & 1286 & 2.7 \\
\hline 10 & $\beta$-Caryophyllene & 1420 & 6.4 \\
\hline 11 & $\alpha$-Caryophyllene & 1454 & 0.7 \\
\hline \multirow[t]{6}{*}{12} & $\alpha$-Farnesene & 1489 & 0.1 \\
\hline & Monoterpenoids & & 15.7 \\
\hline & Sesquiterpenes & & 7.2 \\
\hline & Phenylpropanoid & & 65.2 \\
\hline & Others & & 2.8 \\
\hline & Total & & 90.9 \\
\hline
\end{tabular}

* RI, retention index as determined on a HP-5MS column using the homologous series of $n$-alkanes $\left(\mathrm{C}_{5}-\mathrm{C}_{36}\right)$.

The essential oil from E. yunnanensis rhizomes consisted mainly of phenylpropanoid (estragole), which accounted for $65.2 \%$. Estragole (Figure 1) is a phenylpropene, which consists of a benzene ring substituted with a methoxy group and a propenyl group. It is an isomer of anethole, differing with respect to the location of the double bond [18]. Its name derives from "estragon", the French and German word for tarragon (Artemesia dracunculus), a herb to which it gives its anis-like odor [19]. Furthermore, it is 
also the primary constituent of the essential oil of anise, fennel [20], basil [21,22], Croton zehntneri [23], Clausena anisata [24], Zanthoxylum schinifolium [25,26], Lonicera japonica [27], and so on.

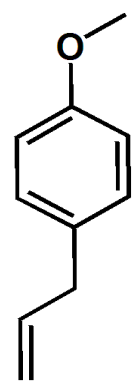

Estragole
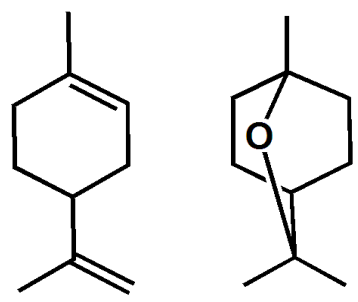

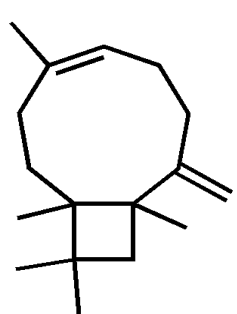

ß-Caryophyllene

Figure 1. The structure of the main components in essential oil.

According to the previous paper about the essential oil from other organs of E. yunnanensis, the main components of the leaves of E. yunnanensis are comprised mainly of germacrene D (19.2\%), $\beta$-pinene (11.6\%), and $\alpha$-amorphene (11.2\%), while the stems are rich in $\beta$-pinene (23.7\%), 1,8-cineole (11.0\%), and $\alpha$-pinene (9.6\%). The major components of the root oil of E. yunnanensis were $\beta$-pinene (31.9\%), $\alpha$-pinene (13.7\%), and 1,8-cineole (9.4\%) [28]. Compared with other parts of E. yunnanensis, the rhizome oil also had some common compounds, including 1,8-cineole and $\alpha$-pinene. However, some compounds like germacrene $\mathrm{D}$ and $\alpha$-amorphene were not detected in the essential oil of its rhizomes. In addition, compared with the other two plants from Etlingera, their essential oils are also characterized by high levels of phenylpropanoids, especially in the rhizomes [29]. These differences in chemical composition and content between the essential oils of leaves, stems, roots, and rhizomes could be due to the different effects of environmental factors (such as sunlight, water, and soil) on the aerial parts and underground parts, or may result from different metabolic pathways in the plant [30]. Thus, further studies on plant cultivation and essential oil standardization are necessary.

\subsection{Contact Toxicity}

The essential oil of E. yunnanensis rhizomes showed contact toxicity against $T$. castaneum adults with a $\mathrm{LD}_{50}$ value of $23.33 \mu \mathrm{g} / \mathrm{adult}$ (Table 2). When compared with the positive control pyrethrum, the essential oil demonstrated 89.62 times less toxic activity against $T$. castaneum adults. E. yunnanensis essential oil also possessed contact toxicity $\left(\mathrm{LD}_{50}=47.38 \mu \mathrm{g} / \mathrm{cm}^{2}\right)$ against the booklice. When compared with the positive control pyrethrum, the essential oil showed 2.53 times less toxic activity against T. castaneum adults (Table 2). However, compared with the other essential oils in the literature, the essential oil of E. yunnanensis possessed stronger contact toxicity against L. bostrychophila than, for example, essential oils of Lonicera japonica ( $\mathrm{LD}_{50}=64.04 \mu \mathrm{g} / \mathrm{cm}^{2}$ ) [27], Litsea cubeba $\left(\mathrm{LD}_{50}=71.56 \mu \mathrm{g} / \mathrm{cm}^{2}\right)$ [31], Foeniculum vulgare $\left(\mathrm{LD}_{50}=90.36 \mu \mathrm{g} / \mathrm{cm}^{2}\right)$ [5], Acorus calamus $\left(\mathrm{LD}_{50}=100.21 \mu \mathrm{g} / \mathrm{cm}^{2}\right)$ [32], Curcuma wenyujin $\left(\mathrm{LD}_{50}=208.85 \mu \mathrm{g} / \mathrm{cm}^{2}\right)$ [33], and Artemisia rupestris $\left(\mathrm{LD}_{50}=418.48 \mu \mathrm{g} / \mathrm{cm}^{2}\right)$ [34]. The concentration-response curves for the two toxicity assays against Tribolium castaneum and Liposcelis bostrychophila were showed in Figure 2. 
Table 2. Contact toxicity of Etlingera yunnanensis rhizomes essential oil and its constituents against Tribolium castaneum (TC) and Liposcelis bostrychophila (LB).

\begin{tabular}{|c|c|c|c|c|c|c|}
\hline Insects & Treatments $* * *$ & $\begin{array}{c}\text { LD }_{50} \\
\left(\mu \mathrm{g} / \mathrm{adult} ; \mu \mathrm{g} / \mathrm{cm}^{2}\right)\end{array}$ & $\begin{array}{c}95 \% \text { FL } \\
\left(\mu \mathrm{g} / \text { adult; } \mu \mathrm{g} / \mathrm{cm}^{2}\right)\end{array}$ & Slope \pm SE & $\begin{array}{c}\text { Chi Square } \\
\left(\chi^{2}\right) \\
\end{array}$ & $p$-Value \\
\hline \multirow{6}{*}{$\mathrm{TC}$} & Essential oil & 23.33 & $20.09-25.27$ & $5.07 \pm 0.57$ & 13.29 & 0.946 \\
\hline & Estragole & 20.41 & $18.95-22.36$ & $5.18 \pm 0.53$ & 15.64 & 0.87 \\
\hline & $\beta$-Caryophyllene & 41.72 & $37.94-45.52$ & $5.28 \pm 0.54$ & 18.58 & 0.725 \\
\hline & 1,8-Cineole & 18.86 & $17.51-20.65$ & $5.04 \pm 0.51$ & 18.00 & 0.757 \\
\hline & Limonene & 13.40 & $11.72-15.49$ & $3.23 \pm 0.41$ & 9.96 & 0.992 \\
\hline & Pyrethrins * & 0.26 & $0.22-0.30$ & $3.34 \pm 0.32$ & 13.11 & 0.950 \\
\hline \multirow{6}{*}{ LB } & Essential oil & 47.38 & $45.66-49.11$ & $14.09 \pm 1.51$ & 10.02 & 0.991 \\
\hline & Estragole & 30.22 & $28.13-32.49$ & $8.04 \pm 0.96$ & 6.25 & 0.995 \\
\hline & $\beta$-Caryophyllene & 74.11 & $71.26-77.75$ & $10.40 \pm 1.08$ & 20.11 & 0.635 \\
\hline & 1,8-Cineole & 321.20 & $302.38-333.90$ & $12.49 \pm 1.31$ & 11.37 & 0.979 \\
\hline & Limonene & 259.62 & $238.13-283.68$ & $5.56 \pm 0.57$ & 16.10 & 0.851 \\
\hline & Pyrethrins ** & 18.72 & $17.60-19.92$ & $2.98 \pm 0.40$ & 10.56 & 0.987 \\
\hline
\end{tabular}

* Data from You et al. [35]; ** data from Yang et al. [31]. *** The mortality of the control (acetone) was $0 \mu \mathrm{g} /$ adult for TC and $0 \mu \mathrm{g} / \mathrm{cm}^{2}$ for LB.

T. castaneum adults

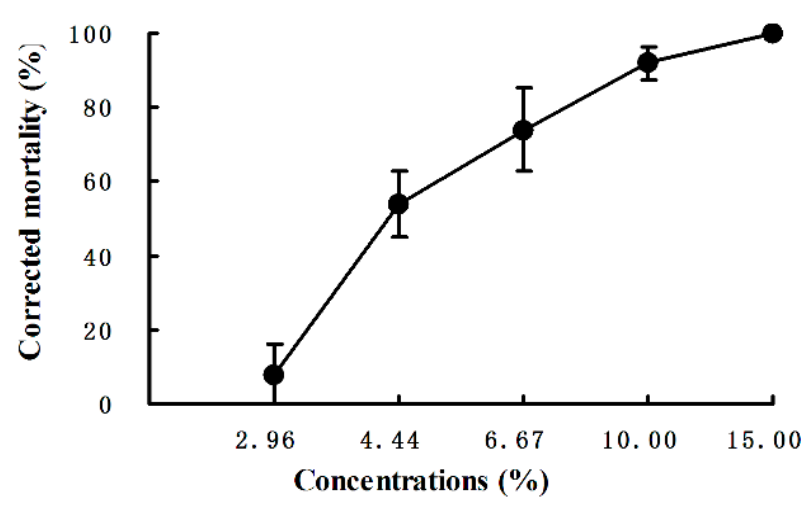

L.bostrychophila adults

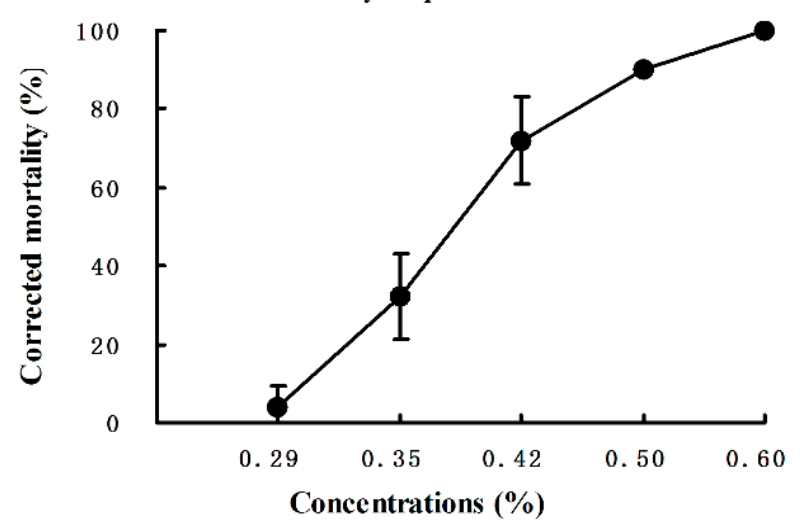

Figure 2. Contact toxicity of Etlingera yunnanensis rhizome essential oil against Tribolium castaneum and Liposcelis bostrychophila.

The main constituent compounds estragole, 1,8-cineole, and limonene exhibited stronger contact toxicity against the red flour beetles, with $\mathrm{LD}_{50}$ values of $20.41,18.86$, and $13.40 \mu \mathrm{g} / \mathrm{adult}$, respectively than the essential oil (Table 2), while $\beta$-caryophyllene exhibited weaker toxicity against $T$. castaneum adults $\left(\mathrm{LD}_{50}=41.72 \mu \mathrm{g} /\right.$ adult$)$. However, only estragole possessed stronger contact toxicity $\left(\mathrm{LD}_{50}=\right.$ $30.22 \mu \mathrm{g} / \mathrm{cm}^{2}$ ) than the essential oil against the booklice. The previous reports using a similar bioassay method also mentioned the contact activity of the four constituents and the results were about the same $[26,27,31,35,36]$. Therefore, as the uppermost constituent in the essential oil of E. yunnanensis, estragole is one of the contributors to the contact activity of the essential oil. Furthermore, estragole had been shown to exhibit contact toxicity against several stored product insects such as Sitophilus zeamais [22,25], Sitophilus oryza, Callosobruchus chinensis, and Lasioderma serricorne [37]. Moreover, some modes of action of estragole were also found. From electrophysiological experiments, Huignard et al. observed 
that estragole specifically induces a reduction of posthyperpolarization [38]. Additionally, a prior study about acetylcholinesterase demonstrated that estragole, as well as $s$-carvone and camphor, produced a mixed inhibition for this enzyme, binding either to the free enzyme or to the enzyme-substrate complex but linking to a site different from the active site where the substrate binds [39]. Thus, the insecticidal activity of the essential oil of E. yunnanensis and estragole was quiet promising.

On the other hand, as the uppermost constituent in the essential oil of E. yunnanensis rhizomes, estragole has been demonstrated to be genotoxic and carcinogenic. Consequently, reductions in exposure and restrictions in use levels as a flavoring substance have been recommended by the Scientific Committee on Food [40]. European Union regulations on flavorings have also established maximum levels for estragole in certain compound foods resulting from the use of food ingredients in which it naturally occurs [41]. Moreover, based on the adverse effects and risk assessments, the security doses of some main constituents must be studied further [42]. This point is best illustrated with the example of 1,8-cineole. This constituent can be used internally as a flavoring and medicinal ingredient at very low doses, but it is toxic if ingested in greater than normal doses. Although this medicinal herb is safe for human consumption because it has been used as a folk medicinal herb for hundreds of years, no experimental data about its safety is available so far. Essential oils are indeed natural, but this origin does not imply that they are safe. In terms of toxicokinetics and ecotoxicology, essential oils also have some potential problems [3]. The latter observations imply that use of essential oils can be not safe for beneficial insects as natural enemies and pollinators. Thus, to develop a practical application for the essential oil and estragole as novel insecticides, further research on the safety and effectiveness of the essential oil for humans is needed.

\subsection{Repellency}

The results of repellency assays for the essential oil against the two species of stored product insects were presented in Tables 3 and 4 and Figure 3. Data showed that at tested concentrations, the essential oil possessed strong repellency against $T$. castaneum adults. At the lowest assayed concentration $\left(0.13 \mathrm{~nL} / \mathrm{cm}^{2}\right)$, the essential oil still showed 36\% repellency against the beetles at $4 \mathrm{~h}$ after exposure. However, the essential oil only exhibited strong repellency against L. bostrychophila at the dose of $12.63 \mathrm{~nL} / \mathrm{cm}^{2}$ and $2.53 \mathrm{~nL} / \mathrm{cm}^{2}$. At the other concentrations, the two compounds showed some insect-attractant properties.

The four main constituents showed different repellent activity against the two stored product insects (Tables 3 and 4). At the concentration of $15.73 \mathrm{~nL} / \mathrm{cm}^{2}$, estragole, $\beta$-caryophyllene, and limonene showed strong (Class V) repellency $(94 \%, 80 \%$, and $88 \%$ ) against $T$. castaneum adults at $2 \mathrm{~h}$ after exposure (Table 3), while 1,8-Cineole exhibited moderate (Class III) repellency (50\%) against the red flour beetles. However, estragole, $\beta$-caryophyllene, 1,8-cineole, and limonene all showed a lower level of repellency (54\%, 36\%, 38\%, and 64\%, respectively) against L. bostrychophila at the dose of $12.63 \mathrm{~nL} / \mathrm{cm}^{2}$ after $2 \mathrm{~h}$ treatment (Table 4).

In previous reports, estragole, limonene, 1,8-cineole, and $\beta$-caryophyllene all showed repellent activity against the red flour beetles, and Yang et al. reported the repellency of limonene against booklice $[31,35,36]$. Many essential oils and their constituents were evaluated for repellency against insects as well [43]. The data and literature survey has indicated that the bioactivity properties of 
essential oils may be related to the synergistic effects of their diverse major and minor components [35]. This paper reported that the essential oil of E. yunnanensis had contact and repellent activities to red flour beetles and booklice for the first time. These findings, considered together, suggest that the essential oil showed potential for development as a natural insecticide/repellent for stored products.
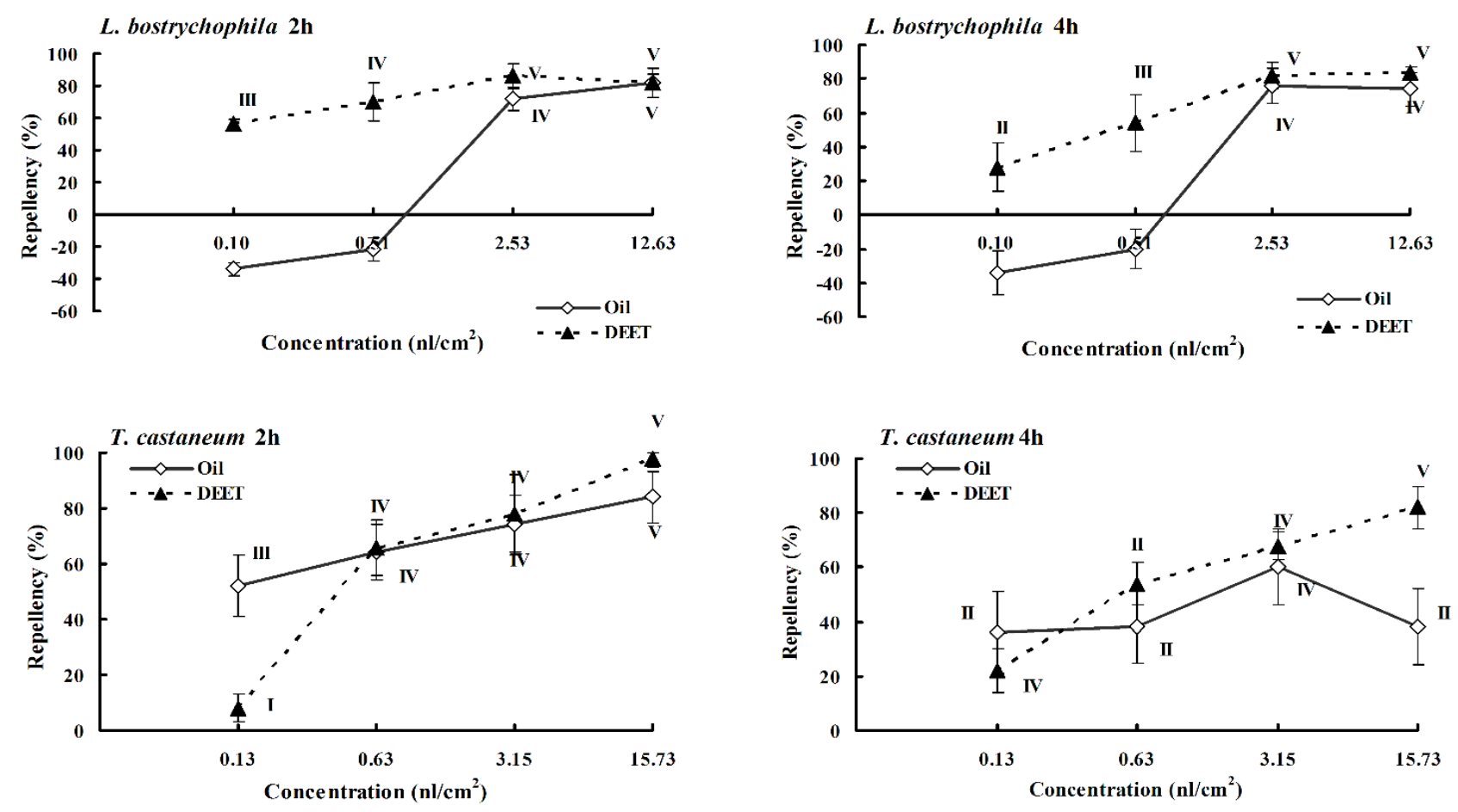

Figure 3. Percentage repellency of DEET and the essential oil from Etlingera yunnanensis rhizomes against Tribolium castaneum and Liposcelis bostrychophila at $2 \mathrm{~h}$ and $4 \mathrm{~h}$ after exposure. The averages were assigned to different classes ( 0 to $\mathrm{V}$ ) using percentage repellency. Vertical error bars indicated standard error of mean.

Table 3. Percentage repellency (PR) after two exposure times for the essential oil and its constituents against Tribolium castaneum (TC) adults ${ }^{\text {a }}$.

\begin{tabular}{|c|c|c|c|c|c|}
\hline \multirow{2}{*}{ Insect } & \multirow{2}{*}{ Treatment } & \multicolumn{4}{|c|}{$2 \mathrm{~h} / 4 \mathrm{~h}\left(\mathrm{~nL} / \mathrm{cm}^{2}\right)$} \\
\hline & & 15.73 & 3.15 & 0.63 & 0.13 \\
\hline \multirow{6}{*}{$\mathrm{TC}$} & Essential oil & $84 \pm 9 a b ; 38 \pm 14 a$ & $74 \pm 11 b ; 60 \pm 14 a$ & $64 \pm 10 \mathrm{a} ; 38 \pm 13 \mathrm{a}$ & $52 \pm 11 b c ; 36 \pm 15 a b$ \\
\hline & Estragole & $94 \pm 6 b ; 82 \pm 5 b$ & $88 \pm 5 b ; 68 \pm 15 a$ & $78 \pm 13 \mathrm{a} ; 64 \pm 15 \mathrm{a}$ & $58 \pm 13 \mathrm{bc} ; 48 \pm 16 \mathrm{ab}$ \\
\hline & $\beta$-Caryophyllene & $80 \pm 8 \mathrm{ab} ; 98 \pm 3 \mathrm{~b}$ & $68 \pm 8 \mathrm{ab} ; 90 \pm 5 \mathrm{a}$ & $38 \pm 12 \mathrm{a} ; 36 \pm 13 \mathrm{a}$ & $36 \pm 14 \mathrm{ab} ; 34 \pm 13 \mathrm{ab}$ \\
\hline & 1,8-Cineole & $50 \pm 13 a ; 74 \pm 16 a b$ & $28 \pm 14 \mathrm{a} ; 54 \pm 15 \mathrm{a}$ & $42 \pm 16 \mathrm{a} ; 38 \pm 12 \mathrm{a}$ & $28 \pm 14 \mathrm{ab} ; 40 \pm 10 \mathrm{ab}$ \\
\hline & Limonene & $88 \pm 14 b ; 94 \pm 8 b$ & $70 \pm 9 b ; 56 \pm 16 a$ & $76 \pm 11 \mathrm{a} ; 56 \pm 14 \mathrm{a}$ & $78 \pm 10 \mathrm{c} ; 70 \pm 12 b$ \\
\hline & DEET & $98 \pm 3 b ; 82 \pm 8 b$ & $78 \pm 14 b ; 68 \pm 5 a$ & $66 \pm 10 \mathrm{a} ; 54 \pm 8 \mathrm{a}$ & $8 \pm 5 a ; 22 \pm 8 a$ \\
\hline
\end{tabular}

${ }^{a}$ Means in the same column followed by the same letters do not differ significantly $(p>0.05)$ in ANOVA and

Tukey's tests. PR was subjected to an arcsine square-root transformation before ANOVA and Tukey's tests. 
Table 4. Percentage repellency (PR) after two exposure times for the essential oil and its constituents against Liposcelis bostrychophila (LB) ${ }^{\text {a }}$.

\begin{tabular}{|c|c|c|c|c|c|}
\hline \multirow{2}{*}{ Insect } & \multirow{2}{*}{ Treatment } & \multicolumn{4}{|c|}{$2 \mathrm{~h} / 4 \mathrm{~h} \mathrm{~nL} / \mathrm{cm}^{2}$} \\
\hline & & 12.63 & 2.53 & 0.51 & 0.10 \\
\hline \multirow{6}{*}{ LB } & Essential oil & $82 \pm 9 \mathrm{ab} ; 74 \pm 10 \mathrm{a}$ & $72 \pm 7 \mathrm{a} ; 76 \pm 10 \mathrm{a}$ & $-22 \pm 7 \mathrm{a} ;-20 \pm 12 \mathrm{a}$ & $-34 \pm 4 b c ;-34 \pm 13 a b$ \\
\hline & Estragole & $-54 \pm 9 b ;-40 \pm 3 b$ & $76 \pm 6 a ; 38 \pm 16 a$ & $0 \pm 16 \mathrm{a} ; 20 \pm 15 \mathrm{a}$ & $22 \pm 11 \mathrm{bc} ;-30 \pm 12 \mathrm{ab}$ \\
\hline & $\beta$-Caryophyllene & $36 \pm 8 \mathrm{ab} ; 24 \pm 18 \mathrm{~b}$ & $-24 \pm 8 \mathrm{ab} ; 32 \pm 14 \mathrm{a}$ & $24 \pm 16 \mathrm{a} ; 42 \pm 14 \mathrm{a}$ & $24 \pm 15 \mathrm{ab} ; 32 \pm 16 \mathrm{ab}$ \\
\hline & 1,8-Cineole & $38 \pm 14 \mathrm{a} ; 28 \pm 12 \mathrm{ab}$ & $12 \pm 8 \mathrm{a} ; 6 \pm 14 \mathrm{a}$ & $-10 \pm 10 a ; 10 \pm 14 a$ & $-16 \pm 11 \mathrm{ab} ; 14 \pm 11 \mathrm{ab}$ \\
\hline & Limonene & $64 \pm 7 b ; 52 \pm 10 b$ & $30 \pm 10 \mathrm{~b} ; 16 \pm 11 \mathrm{a}$ & $24 \pm 15 \mathrm{a} ; 20 \pm 6 \mathrm{a}$ & $36 \pm 13 c ; 18 \pm 12 b$ \\
\hline & DEET & $82 \pm 5 b ; 84 \pm 3 b$ & $86 \pm 8 b ; 82 \pm 8 a$ & $70 \pm 12 \mathrm{a} ; 54 \pm 17 \mathrm{a}$ & $56 \pm 3 a ; 28 \pm 14 a$ \\
\hline
\end{tabular}

${ }^{a}$ Means in the same column followed by the same letters do not differ significantly $(p>0.05)$ in ANOVA and

Tukey's tests. PR was subjected to an arcsine square-root transformation before ANOVA and Tukey's tests.

\section{Experimental Section}

\subsection{Plant Material and Extractions}

Rhizomes of Etlingera yunnanensis were collected in June 2013 from Yunnan Province, China. The species was identified according to the voucher specimen (BNU-CMH-Dushushan-2013-06-15-015) deposited at the Herbarium of College of Resources Science and Technology, Beijing Normal University. Rhizomes $(1.4 \mathrm{~kg})$ of E. yunnanensis were subjected to hydrodistillation by a modified Clevenger-type apparatus for $6 \mathrm{~h}$ and then extracted with $n$-hexane. After extraction, water in the essential oil was removed by anhydrous sodium sulphate. The essential oil was stored in an airtight container in a refrigerator at $4{ }^{\circ} \mathrm{C}$.

\subsection{Insects}

The T. castaneum and L. bostrychophila were obtained from laboratory cultures maintained for the last two years in incubators at $29 \pm 1{ }^{\circ} \mathrm{C}$ and $70 \%-80 \%$ relative humidity in the dark. Adult $T$. castaneum insects were reared in glass containers $(0.5 \mathrm{~L})$ containing at $12 \%-13 \%$ moisture content on whole wheat mixed with yeast (wheatfeed/yeast, 10:1,w/w) while booklice were reared on a 10:1:1 mixture, by mass, of flour, milk powder, and active yeast. Adults used in all the experiments were about 1-2 weeks old. All the containers housing booklice used in experiments were made escape-proof with a coating of polyterafluoroethylene (Sino-rich ${ }^{\circledR}$, Beijing Sino-rich Tech Co., Ltd., Xuanwu District, Beijing, China).

\subsection{Gas Chromatography and Mass Spectrometry (GC-MS)}

GC-MS analysis was performed on a Thermo Finnigan Trace DSQ instrument equipped with a flame ionization detector and an HP-5MS $(30 \mathrm{~m} \times 0.25 \mathrm{~mm} \times 0.25 \mu \mathrm{m})$ capillary column. The column temperature was programmed at $50{ }^{\circ} \mathrm{C}$ for $2 \mathrm{~min}$, then increased at $2{ }^{\circ} \mathrm{C} / \mathrm{min}$ to the temperature of $150{ }^{\circ} \mathrm{C}$ and held for $2 \mathrm{~min}$, and then increased at $10^{\circ} \mathrm{C} / \mathrm{min}$ until the final temperature of $250{ }^{\circ} \mathrm{C}$ was reached, where it was held for $5 \mathrm{~min}$. The injector temperature was maintained at $250{ }^{\circ} \mathrm{C}$ and the volume injected was $0.1 \mathrm{~mL}$ of $1 \%$ solution (diluted in acetone). The carrier gas was helium at a flow rate of $1.0 \mathrm{~mL} / \mathrm{min}$. Spectra were scanned from 50 to $550 \mathrm{~m} / \mathrm{z}$. Most constituents were identified by comparison of their 
retention indices with those reported in the literatures. The retention indices were determined in relation to a homologous series of $n$-alkanes $\left(\mathrm{C}_{5}-\mathrm{C}_{36}\right)$ under the same operating conditions. GC retention time and their mass spectra that were stored in NIST 05 and Wiley 275 libraries or from literature were used for identifying the essential oil components [44]. Relative percentages of the individual components of the essential oil were obtained by averaging the GC peak area \% reports.

\subsection{Contact Toxicity}

The contact toxicity of the essential oil and the individual compounds against $T$. castaneum adults was measured as described [12]. The four individual compounds (estragole, $\beta$-caryophyllene, 1,8-cineole, and limonene) were obtained from Tokyo Chemical Industry (Shanghai) Development Co., Ltd., Shanghai, China. Aliquots of $0.5 \mu \mathrm{L}$ of the essential oil (diluted with acetone at five different concentrations) were applied topically to the dorsal thorax of the insects (10 insects per replicate, five replicates per dose). Insects treated with acetone alone were used as controls. Both treated and control insects were then transferred to glass vials (10 insects per vial) and kept in incubators. Insect mortality was checked after $24 \mathrm{~h}$, and the LD 50 values were calculated using Probit analysis [45]. Positive control, pyrethrins (pyrethrin I and II, 37\%) were purchased from Dr. Ehrenstorfer GmbH.

The contact toxicity of the essential oil and the individual compounds against L. bostrychophila was tested as described [46]. A $5.5 \mathrm{~cm}$ diameter filter paper was treated with $300 \mu \mathrm{L}$ of the solution of the essential oil. The filter paper after being treated with solid glue was placed in a $5.5 \mathrm{~cm}$ diameter Petri dish (with a coating of polyterafluoroethylene) and 10 booklice were put on the filter paper. A cover was put and all the Petri dishes were kept in incubators. Acetone was used as a negative control. Five concentrations (diluted with acetone) and five replicates of each concentration were used. Mortality of insects was observed after $24 \mathrm{~h}$. The LD50 values were calculated by using Probit analysis [45].

\subsection{Repellency}

The repellent activity of the essential oil and the individual compounds to $T$. castaneum and L. bostrychophila was tested using the area preference method [34]. The essential oil was diluted in acetone to different concentrations $\left(78.63,15.73,3.15,0.63\right.$, and $\left.0.13 \mathrm{~nL} / \mathrm{cm}^{2}\right)$ and acetone was used as the control. Filter paper ( $9 \mathrm{~cm}$ in diameter) was cut in half. $500 \mu \mathrm{L}$ of treatment solution was placed on one half of the filter paper. The other half was treated with $500 \mu \mathrm{L}$ of acetone. The two halves of filter are allowed to dry for $30 \mathrm{~s}$. The treated side was then joined to the control side by tape and placed in glass Petri dishes ( $9 \mathrm{~cm}$ in diameter). As for the booklice, Petri dishes (with a coating of polyterafluoroethylene) and filter papers were changed to $5.5 \mathrm{~cm}$ in diameter and the concentrations of the essential oil used in the experiments were $63.17,12.63,2.53,0.51$, and $0.10 \mathrm{~nL} / \mathrm{cm}^{2}$. The half filter paper was treated with $150 \mu \mathrm{L}$ of the solution. For both tests, 20 insects were released in the center of each filter paper disk, and a cover was placed over the Petri dish. Five replicates were used. Counts of the insects present on each strip were made after 2 and $4 \mathrm{~h}$. The percent repellency (PR) of essential oil was then calculated using the formula:

$$
\operatorname{PR}(\%)=\left[\left(N_{c}-N_{t}\right) /\left(N_{c}+N_{t}\right)\right] \times 100
$$


where $N_{c}$ is the number of insects present in the negative control half and $N_{t}$ is the number of insects present in the treated half. The averages were then assigned to different classes ( 0 to $\mathrm{V}$ ) using the following scale (percentage repellency) [12]. Class, \% repellency: 0, $>0.01$ to $<0.1$; I, 0.1-20.0; II, 20.1-40.0; III, 40.1-60.0; IV, 60.1-80.0; and V, 80.1-100. Means and standard errors were conducted by Microsoft Excel 2007 for Windows XP. Analysis of variance (ANOVA) and Tukey's test were conducted by using SPSS 19.0. Percentage was subjected to arcsine square-root transformation before ANOVA and Tukey's tests. The averages were then assigned to different classes ( 0 to V) (Table 4). A commercial repellent, DEET ( $N, N$-diethyl-3-methylbenzamide), was purchased from the National Center of Pesticide Standards (Shenyang, China) and used as a positive control.

\section{Conclusions}

This work indicates that the essential oil of E. yunnanensis rhizomes and its four constituents have potential for being developed into natural insecticides/repellents for the control of insects in stored products. However, further studies are needed to focus on the safety of the essential oil for humans and to improve the potency and stability of these potential insecticides/repellents for practical use.

\section{Acknowledgments}

This project was supported by the National Natural Science Foundation of China (No. 81374069), Beijing Municipal Natural Science Foundation (No. 7142093) and Fundamental Research Funds for the Central Universities. The authors thank Liu Q.R. from College of Life Sciences, Beijing Normal University, Beijing 100875, for the identification of the investigated medicinal herb.

\section{Author Contributions}

The contributions of the respective authors are as follows: S.-S.D. and N.L. were responsible for the experimental design; J.-Y.L. and S.-S.G. were responsible for the determination of insecticidal activity; Z.-F.G. and C.-F.W. performed research and analyzed the data; S.-S.G. and C.-X.Y. wrote the whole article, including the Discussion and Conclusions; S.-S.D. and W.-J.Z. edited and revised the manuscript. All authors read and approved the final manuscript.

\section{Conflicts of Interest}

The authors declare no conflict of interest.

\section{References}

1. Copping, L.G.; Menn, J.J. Biopesticides: A review of their action, applications and efficacy. Pest Manag. Sci. 2000, 8, 651-676.

2. Isman, M.B. Botanical insecticides, deterrents, and repellents in modern agriculture and an increasingly regulated world. Annu. Rev. Entomol. 2006, 51, 45-66.

3. Regnault-Roger, C.; Vincent, C.; Arnason, J.T. Essential oils in insect control: Low-risk products in a high-stakes world. Annu. Rev. Entomol. 2012, 57, 405-424. 
4. Kim, S.I.; Roh, J.Y.; Kim, D.H.; Lee, H.S.; Ahn, Y.J. Insecticidal activities of aromatic plant extracts and essential oils against Sitophilus oryzae and Callosobruchus chinensis. J. Stored Prod. Res. 2003, 39, 293-303.

5. Zhao, N.N.; Zhou, L.G.; Liu, Z.L.; Du, S.S.; Deng, Z.W. Evaluation of the toxicity of the essential oils of some common Chinese spices against Liposcelis bostrychophila. Food Control. 2012, 26, 486-490.

6. Zhu, W.X.; Zhao, K.; Chu, S.S.; Liu, Z.L. Evaluation of essential oil and its three main active ingredients of Chinese Chenopodium ambrosioides (Family: Chenopodiaceae) against Blattella germanica. J. Arthropod Borne Dis. 2012, 6, 90-97.

7. Liang, Y.; Li, J.L.; Xu, S.; Zhao, N.N.; Zhou, L.G.; Cheng, J.; Liu, Z.L. Evaluation of repellency of some Chinese medicinal herbs essential oils against Liposcelis bostrychophila (Psocoptera: Liposcelidae) and Tribolium castaneum (Coleoptera: Tenebrionidae). J. Econ. Entomol. 2013, 106, 513-519.

8. Mohamed, M.I.; Abdelgaleil, S.A.M. Chemical composition and insecticidal potential of essential oils from Egyptian plants against Sitophilus oryzae (L.) (Coleoptera: Curculionidae) and Tribolium castaneum (Herbst) (Coleoptera: Tenebrionidae). Appl. Entomol. Zool. 2008, 43, 599-607.

9. Liu, Z.L.; Yu, M.; Li, X.M.; Wan, T.; Chu, S.S. Repellent activity of eight essential oils of Chinese medicinal herbs to Blattella germanica L. Rec. Nat. Prod. 2011, 5, 176-183.

10. Ding, W.; Liu, H.; Long-Shu, L.I. The main stratagems and technology for stored product pest control in ancient China. J. Southwest Agric. Univ. 2000, 22, 335-338.

11. Yang, K.; You, C.X.; Wang, C.F.; Guo, S.S.; Li, Y.P.; Wu,Y.; Geng, Z.F.; Deng, Z.W.; Du, S.S. Composition and repellency of the essential oils of Evodia calcicola Chun ex Huang and Evodia trichotoma (Lour.) Pierre against three stored product insects. J. Oleo Sci. 2014, 63, 1169-1176.

12. Qian, X.H. Flora Reipublicae Popularis Sinicae; Science Press: Beijing, China, 1981; Volume 16, p. 137.

13. Liu, Z.L.; Ho, S.H. Bioactivity of the essential oil extracted from Evodia rutaecarpa Hook f. et Thomas against the grain storage insects, Sitophilus zeamais Motsch. and Tribolium castaneum (Herbst). J. Stored Prod. Res. 1999, 35, 317-328.

14. Magan, N.; Hope, R.; Cairns, V.; Aldred, D. Postharvest fungal ecology: Impact of fungal growth and mycotoxin accumulation in stored grain. Eur. J. Plant. Pathol. 2003, 109, 723-730.

15. Nayak, M.K.; Daglish, G.J.; Byrne, V.S. Effectiveness of spinosad as a grain protectant against resistant beetle and psocid pests of stored grain in Australia. J. Stored Prod. Res. 2005, 41, 455-467.

16. Zhou, T. Studies on Reproductive Strategy of Two Species in Etlingera. Master's Thesis, South China Normal University, Guangzhou, China, 2012.

17. State administration of traditional Chinese medicine. Chinese Materia Medica (No. 34); Shanghai Scientific and Technical Publishers: Shanghai, China, 2005; pp. 173-174.

18. Fahlbusch, K.G.; Hammerschmidt, F.J.; Panten, J.; Pickenhagen, W.; Schatkowski, D.; Bauer, K.; Garbe D.; Surburg, H. Flavors and fragrances. In Ullmann's Encyclopedia of Industrial Chemistry; Wiley-VCH: Weinheim, Germany, 2003.

19. Misztal, P.K.; Owen, S.M.; Guenther, A.B.; Rasmussen, R.; Geron, C.; Harley, P.; Phillips, G.J.; Ryan, A.; Edwards, D.P.; Hewitt, C.N. Large estragole fluxes from oil palms in Borneo. Atmos. Chem. Phys. 2010, 10, 4343-4358. 
20. Zeller, A.; Rychlik, M. Impact of estragole and other odorants on the flavour of anise and tarragon. Flavour Fragr. J. 2007, 22, 105-113.

21. Chang, C.L.; Cho, I.K.; Li, Q.X. Insecticidal activity of basil oil, trans-anethole, estragole, and linalool to adult fruit flies of Ceratitis capitata, Bactrocera dorsalis, and Bactrocera cucurbitae. J. Econ. Entomol. 2009, 102, 203-209.

22. Kim, S.; Lee, D. Toxicity of basil and orange essential oils and their components against two coleopteran stored products insect pests. J. Asia-Pac. Entomol. 2014, 17, 13-17.

23. Albuquerque, A.A.; Sorenson, A.L.; Lealcardoso, J.H. Effects of essential oil of Croton zehntneri, and of anethole and estragole on skeletal muscles. J. Ethnopharmacol. 1995, 49, 41-49.

24. Okunade, A.L.; Olaifa, J.I. Estragole: An acute toxic principle from the volatile oil of the leaves of Clausena anisata. J. Nat. Prod. 1987, 50, 990-991.

25. Wang, C.F.; Yang, K.; Zhang, H.M.; Cao, J.; Fang, R.; Liu, Z.L.; Du, S.S.; Wang, Y.Y.; Deng, Z.W.; Zhou, L.G. Components and insecticidal activity against the maize weevils of Zanthoxylum schinifolium fruits and leaves. Molecules 2011, 16, 3077-3088.

26. Wang, C.F. Chemical Constituents and their Bioactivities of Zanthoxylum Plants against Stored-Product Insects in Chinese Medicinal Materials. Ph.D. Thesis, Beijing Normal University, Beijing, 2013.

27. Zhou, H.Y.; Zhao, N.N.; Du, S.S.; Yang, K.; Wang, C.F.; Liu, Z.L.; Qiao, Y.J. Insecticidal activity of the essential oil of Lonicera japonica flower buds and its main constituent compounds against two grain storage insects. J. Med. Plants Res. 2012, 6, 912-917.

28. Chau, D.T.; Hoi, T.M.; Thai, T.H.; Thang, T.D.; Ogunwande, I.A. Essential oil constituents of Etlingera yunnanensis and Hornstedtia sanhan grown in Vietnam. Nat. Prod. Commun. 2015, 10, $365-366$.

29. Wong, K.C.; Sivasothy, Y.; Boey, P.L.; Osman, H.; Sulaiman, B. Essential oils of Etlingera elatior (Jack) R.M. Smith and Etlingera littoralis (Koenig) Giseke. J. Essent. Oil Res. 2010, 22, 461-466.

30. Wang, C.F.; Yang, K.; You, C.X.; Zhang, W.J.; Guo, S.S.; Geng, Z.F.; Du, S.S.; Wang, Y.Y. Chemical composition and insecticidal activity of essential oils from Zanthoxylum dissitum leaves and roots against three species of storage pests. Molecules 2015, 20, 7990-7999.

31. Yang, K.; Wang, C.F.; You, C.X.; Geng, Z.F.; Sun, R.Q.; Guo, S.S.; Du, S.S.; Liu, Z.L.; Deng, Z.W. Bioactivity of essential oil of Litsea cubeba from China and its main compounds against two stored product insects. J. Asia-Pac. Entomol. 2014, 17, 459-466.

32. Liu, X.C.; Zhou, L.G.; Liu, Z.L.; Du, S.S. Identification of insecticidal constituents of the essential oil of Acorus calamus rhizomes against Liposcelis bostrychophila Badonnel. Molecules 2013, 8, 5684-5696.

33. Liu, Z.L.; Zhao, N.N.; Liu, C.M.; Zhou, L.G.; Du, S.S. Identification of insecticidal constituents of the essential oil of Curcuma wenyujin rhizomes active against Liposcelis bostrychophila Badonnel. Molecules 2012, 17, 12049-12060.

34. Liu, X.C.; Li, Y.P.; Li, H.Q.; Deng, Z.W.; Zhou, L.G.; Liu, Z.G.; Du, S.S. Identification of repellent and insecticidal constituents of the essential oil of Artemisia rupestris L. aerial parts against Liposcelis bostrychophila Badonnel. Molecules 2013, 18, 10733-10746.

35. You, C.X.; Yang, K.; Wu,Y.; Zhang, W.J.; Wang, Y.; Geng, Z.F.; Chen, H.P.; Jiang, H.Y.; Du, S.S.; Deng, Z.W. Chemical composition and insecticidal activities of the essential oil of Perilla frutescens (L.) Britt aerial parts against two stored product insects. Eur. Food Res. Technol. 2014, 239, 481-490. 
36. Zhang, W.J.; You, C.X.; Yang, K.; Wang, Y.; Su, Y.; Geng, Z.F.; Du, S.S.; Wang, C.F.; Deng, Z.W.; Wang, Y.Y. Bioactivity and chemical constituents of the essential oil from Dendranthema indicum (L.) Des Moul against two stored insects. J. Oleo Sci. 2015, 64, 553-560.

37. Kim, D.H.; Ahn, Y.J. Contact and fumigant activities of constituents of Foeniculum vulgare fruit against three coleopteran stored-product insects. Pest. Manag. Sci. 2001, 57, 301-306.

38. Huignard, J.; Lapied, B.; Dugravot, S.; Magnin-Robert, M.; Ketoh, G.K. Modes d'action neurotoxiques des dérivés Soufrés et de certaines huiles essentielles et risques liés à leur utilisation. In Biopesticides D’origine Végétale, 2nd ed.; Lavoisier: Paris, France, 2008; pp. 219-231.

39. López, M.D.; Pascual-Villalobosa, M.J. Mode of inhibition of acetylcholinesterase by monoterpenoids and implications for pest control. Ind. Crops Prod. 2010, 31, 284-288.

40. Opinion of the Scientific Committee on Food on Estragole (1-Allyl-4-methoxybenzene). Available online: http://ec.europa.eu/food/fs/sc/scf/out104_en.pdf (accessed on 5 October 2001).

41. Regulation (EC) No 1334/2008 of the European Parliament and of the Council of 16 December 2008 on Flavourings and Certain Food Ingredients with Flavouring Properties for Use in and on Foods and Amending Council. Regulation (EEC) No 1601/91, Regulations (EC) No 2232/96 and (EC) No 110/2008 and Directive 2000/13/EC. Available online: http://eur-lex.europa.eu/legalcontent/EN/TXT/?qid=1440545390594\&uri=CELEX:32008R1334 (accessed on 16 December 2008).

42. Carratù, B.; Federici, E.; Gallo, F.R.; Geraci, A.; Guidotti, M.; Multari, G.; Palazzino, G.; Sanzini, E. Plants and parts of plants used in food supplements: An approach to their safety assessment. Ann. Ist. Super. Sanità 2010, 46, 370-388.

43. Nerio, L.S.; Olivero-Verbel, J.; Stashenko, E. Repellent activity of essential oils: A review. Bioresour. Technol. 2010, 101, 372-378.

44. Adams, R.P. Identification of Essential oil Components by Gas Chromatography/Quadrupole Mass Spectroscopy; Allured: Carol Stream, IL, USA, 2001.

45. Sakuma, M. Probit analysis of preference data. Appl. Entomol. Zool. 1998, 33, 339-347.

46. Zhang, J.S.; Zhao, N.N.; Liu, Q.Z.; Liu, Z.L.; Du, S.S.; Zhou, L.G.; Deng, Z.W. Repellent constituents of essential oil of Cymbopogon distans aerial parts against two stored-product insects. J. Agric. Food Chem. 2011, 59, 9910-9915.

Sample Availability: Samples of the compounds are available from the authors.

(C) 2015 by the authors; licensee MDPI, Basel, Switzerland. This article is an open access article distributed under the terms and conditions of the Creative Commons Attribution license (http://creativecommons.org/licenses/by/4.0/). 